\title{
Communication in Crises: How Dialogues Mediate Actions
}

\author{
Kristian Firing ${ }^{1 *}$, Kåre Inge Skarsvåg ${ }^{2}$, Tatiana Chemi ${ }^{3}$ and May Britt Postholm ${ }^{1}$ \\ ${ }^{1}$ Department of Teacher Education, Faculty of Social and Educational Sciences, Norwegian University of Science \\ and Technology, Trondheim, Norway, ${ }^{2}$ Norwegian Defence University College, Oslo, Norway, ${ }^{3}$ Department of Learning \\ and Philosophy, Aalborg University, Aalborg, Denmark
}

Personnel from the armed forces, police, and health services are subject to splitsecond bias when interacting in crises, however, when it comes to communication and negotiations, deep knowledge about the dialogues is still unexplored. Our objective in this article is to achieve a better understanding of how emergency personnel use dialogue to mediate other peoples' actions in critical situations, and how the new knowledge can help these professionals to increase their impact. Our research has been guided by the following research question: When in a crisis, how do emergency personnel's utterances function as auxiliary stimuli to mediate other peoples' higherorder thinking and voluntary action? Using a multiple case study design, emergency personnel from the armed forces, the police and the health services in Norway shared their experience from crises, encompassing three cases: (1) The Coaching in Crossfire, (2) The Axe Desperado and (3) The Still Face. Analysis of the qualitative data revealed

OPEN ACCESS

Edited by:

Giuseppe Craparo, Kore University of Enna, Italy

Reviewed by: Mare Koit

University of Tartu, Estonia Yongchuan Shi,

Wenzhou University, China

*Correspondence: Kristian Firing Kristian.firing@ntnu.no

Specialty section:

This article was submitted to Educational Psychology,

a section of the journal

Frontiers in Education

Received: 18 April 2020

Accepted: 31 July 2020

Published: 26 August 2020

Citation:

Firing K, Skarsvåg Kl, Chemi T and Postholm MB (2020)

Communication in Crises: How

Dialogues Mediate Actions.

Front. Educ. 5:154

doi: 10.3389/feduc.2020.00154 the following findings, divided into five categories: (1) Unlocking Situations, (2) The Chain of Utterances, (3) The Impact of Auxiliary Stimulus, (4) The Mediation of Higher Mental Functions and (5) Renewed Volitional Action. We discuss our findings in the light of established perspectives associated with expertise, relations, emotions, and the Pygmalion Effect. Our research improves the knowledge on the potential of dialogue as a shared relational process, even when people are in a crisis situation. Thus, our research has practical implications for emergency personnel in relation to crisis management, as well as for human relations when a crisis suddenly occurs.

Keywords: education, crises management, dialogues, mediated actions, higher order thinking

\section{INTRODUCTION}

Emergency personnel often face a dilemma: Sometimes they have to act immediately to solve an impelling situation within seconds, other times they need to refrain from taking action and invite the person(s) in question into a dialogue. The Standard Operating Procedure (SOP) approach to a crisis differs from the dialogue approach because inviting someone into a dialogue means being open, vulnerable, and responsible, and includes adopting the other's perspective, while SOP argues for standard approaches across situations. Dialogue shapes a shared process to make people think, feel, and act differently, even in a crisis with limited space and time resources.

Police interaction involving firearms is often planned armed action, however, sometimes this involves a sudden encounter with an unexpectedly armed opponent (Knutsson and Strype, 2003). In the former, personnel use a relevant Standard Operating Procedure (SOP), for instance a model encompassing different stages or phases (Flin, 1996). In the latter, this is not an option as the incident explodes in seconds and requires immediate response, literally in a split second. 
The problem, addressed in "the split-second syndrome," is that decisions may be influenced by cognitive bias leading to fatal mistakes. The probability of police officers choosing to fire their gun increases when the suspect has a knife, or when firearms are present, and if the incident occurs indoors, the odds of firing increase even more (Knutsson and Strype, 2003).

To counter the split-second bias, the police have had a long tradition of communication and negotiations. Greenstone offers communications skills, such as listening effectively, using questions successfully, dealing with silence, and making a timely response (Greenstone, 2004). In crisis negotiations, some models are based on a rational business-orientated approach that falls short against the emotionally driven and multi-faceted context of a crisis. Other models take a more therapeutic approach, with the emphasis on de-escalating subject emotional arousal and building relationships to successfully resolve the incident (Grubb et al., 2020). Instead of looking at emotions as irrational and negative, researchers "conceptualize emotions holistically as an embodied phenomenon that mediates the social process of leadership" (Drodge and Murphy, 2002). Within the tradition of communication and negotiations, the dialogue process receives little attention, and remains unclear: There is a gap in our understanding of how dialogue can mediate thinking and action in a crisis situation.

Our aim in this article is to arrive at a better understanding of how emergency personnel use dialogue to mediate other peoples' actions in critical situations, and how new knowledge can help these professionals to increase their impact. Our research was guided by the following research question: When in a crisis, how do emergency personnel's utterances function as auxiliary stimuli to mediate other peoples' higher-order thinking and voluntary action?

This paper proceeds by elaborating on key concepts, such as dialogue, utterances, double stimulation, auxiliary stimulus, semiotic mediation, higher-order thinking, conflicting motives, and human volition (Vygotsky, 1925/1979, 1931/1994, 1978, 1986, 1997a,b; Bakhtin, 1986, 1998; Sannino, 2015). Then, we will present the methodology section, a case study of three different situations. By exploring real-world experiences of professionals serving in crisis situations, we were able to grasp the underlying mechanisms of the dialogue. Moreover, we outline the findings, which encompass three narratives and five dialogue categories. Finally, we discuss our findings to refine this article's practical and theoretical contributions.

Our point of departure is that the self is responsive through person-situation interactions (Brewer and Gardner, 1996). A person's behavior is not stable across situations, and both person variables and situation variables are equal contributors to behavior (Mischel, 2004). In crises, professionals may be stressed and the time available may be limited. In Norway, military personnel went berserk when undergoing training, as officer cadets fired their guns at people with what they thought was live ammunition during a stressful military exercise (Larsen, 2001). The police were accused of misconduct in the Obiora case in which a black man died while being arrested by the police in Trondheim (Berglund, 2007). Health personnel were accused of discrimination in the Ali case in which citizens were denied medical assistance in Oslo (Berglund, 2008). Some people are overwhelmed in person-situation interactions and fail to follow the proper SOP or fail to take advantage of dialogue. Other people use these interactions to their advantage.

In the traditional communication model, the transmitter must encode a message, transmit it through a channel and then it is decoded by the receiver. From here, the receiver will take on the position as transmitter and go through the same procedure to transmit his message to the other party (Shannon and Weaver, 1949). Bakhtin offers an alternative perspective, arguing that both parties are active in relation to the other. The listener takes an active, responsive attitude toward the meaning of speech while listening, something the speaker is oriented toward while speaking (Bakhtin, 1986, p. 69). The parties mutually affect each other in the dialogue, inasmuch it becomes impossible to separate the parties. Entering into a dialogue does not mean that you are neutrally delivering a message, rather it means that you are subject to change in relation to the other.

Bakhtin uses the term utterance as an analytical unit of language in social contexts. An utterance could be a word, a sentence, or more sentences, it could even be non-verbal (Bakhtin, 1998). The utterance encompasses the social dimension through the terms "answer," "voice," and "recipient." Answer implies that human beings are in a dialogical position where they must answer for their space, for their identity, to respond to their surroundings. Voice is more than the words of an expression: it represents the individuals' personality (Bakhtin, 1998). Recipient means that utterances are formed according to whom we address, they reveal the other's presence in the dialogue. Beyond this, it is evident that utterances are not indifferent to one another, they mutually reflect one another as "a link in the chain of speech communication" (Wertsch, 1991, p. 52). The utterance is the key unit of analysis for understanding dialogue in communication.

Double stimulation is a method of objectification of inner psychological processes (Sannino, 2015, p. 3). It is based on two groups of stimuli: "One group of stimuli has the function of a task toward which the activity of the experimental subject is directed, whilst the other takes on the function of signs which help to organize the activity" (Vygotsky, 1931/1994, p. 208). Triggered by an initial problematic situation of first stimulus, a second stimulus is an artifact that has become a link between the outside world and inner psychological functioning. The second stimulus must be an appropriate one: "We must not bring forth any process of behavior and control it other than by creating appropriate stimuli" (Vygotsky, 1997b, p. 210). People should not move too fast, not even when they have the motives and intended action in sight. The extremely complicated equilibrium in the nervous system is based on a struggle of competing reflexes. One should be careful as "the outcome of the struggle is often decided by the quite insignificant strength of a new stimulus" (Vygotsky, $1925 / 1979$, p. 18). Even our smallest and most insignificant actions and reactions can play a dominant role depending on how they fit into the complex situation in which first and second types of stimuli coexist. The second stimulus that emergency personnel add to the situation may play a crucial mediating function in relation to higher-order thinking. 
People are social beings who use culturally created means to understand their encounter with the world. When it comes to our use of tools, language is perhaps the most prominent. Vygotsky looks at the social speech humans use when communicating with each other. In addition to this everyday speech, humans learn an inner speech used during problem solving. In this latter case, individuals use language to reason about complex issues (Vygotsky, 1986). The use of tools changes the human approach, physically or psychologically; it mediates action or thinking (Vygotsky, 1978). Wertsch employs the concept "semiotic mediation" to explain how we use signs, such as letters and numbers, in our thinking on a higher level (Wertsch, 1998, p. 28). When it comes to double stimulation, the new stimuli that play the role of stimuli-means enable a transition from a lower to a higher form of thinking, on the basis of which a change in behavior occurs. "The lower mental functions begin to be mediated by a new system of stimuli-means that carry out a new function in the organization of behavior" (Matiyshkin, 1997, p. 266). Mediational means can be created with the intent of shaping other individuals' actions.

Conflict of motives is part of the process of volitional action. A conflict of motives denotes a jump between opposite tendencies that occur in situations where individuals may feel uncertain about their affects and how to behave. Thus, a conflict of motives constitutes the core of a strategic setup that human beings establish to intentionally affect their behavior and the world around them (Sannino, 2015, p. 2). At some point individuals make a connection between an external stimulus and the decided reaction: The two kinds of stimulus-means integrate into "the goal directed effort" (Valsiner, 2000, p. 80). Volitional action is "carried out under conditions of polymotivation, when different motives have different affective signs, that is, some are positive and others are negative" (Leont'ev, 2005, p. 80). Vygotsky elaborated further on consciousness and free will, arguing that a volitional act is based on our awareness of certain wishes and strivings associated with the representation of the ultimate goal and with the representation of the necessary actions to realize the goal (Vygotsky, 1926/1997, p. 167-168). Humans do not only create tools for work, but also the stimuli that regulate behavior and give power to our will (Vygotsky, 1999, p. 63).

Emergency personnel undergo comprehensive training in communication and crisis negotiations to perform in severe stress situations (Drodge and Murphy, 2002; Greenstone, 2004; Grubb et al., 2020). However, there are several examples showing how emergency personnel from the armed forces, police, and health services are subject to split-second bias when interacting in a crisis (Larsen, 2001; Berglund, 2007, 2008).

Within the communication and negotiations tradition, the dialogue process is given little attention and remains unclear. However, there is an abundance of literature that explores Vygotsky's concepts of semiotic mediation and higher development processes further into processes such as double stimulation, higher-order thinking, conflict of motives and human volition (Vygotsky, 1925/1979, 1931/1994, 1978, 1986, 1997a,b; Sannino, 2015). But examples of how these concepts play out in crisis situations are lacking. There seems to be a gap in our understanding of how the dialogue can mediate thinking and action in crises. The present study aims to contribute knowledge to this field.

Emergency personnel from the armed forces, the police and the health services in Norway have shared their experiences from a crisis, facing the dilemma of acting out versus inviting into dialogue. Below is a brief description of the context for our study.

\section{MATERIALS AND METHODS}

With the overriding aim of exploring how emergency personnel use dialogue to mediate other peoples' actions in a critical situation, we chose the case study methodological approach, as case studies explore a bounded system, meaning bounded in time and place. Moreover, as we wanted to explore different situations and contexts, we chose a multiple case study design (Creswell, 2007). Emergency personnel from the armed forces, the police, the fire fighters and the health services in Norway were selected for investigation because they were well known for having experience from crisis situations involving the dilemma of taking action on the one hand and inviting into a dialogue on the other.

In the beginning, this study encompassed 16 cases, from emergency personnel from the armed forces, the police, the fire fighters and the health services. Through what Creswell (2007, p. 125) name as "purposeful sampling," we looked for the cases that could purposefully inform and explore our study's aim and research question: "When in a crisis, how do emergency personnel's utterances function as auxiliary stimuli to mediate other peoples' higher-order thinking and voluntary action?"

In line with Creswell advice for case study research, not to include more than four or five studies in a case study design, we entered into a selection process with the need to identify themes of each case as well as having cases suitable for cross-case theme analysis. In this process, the "maximum variation" criteria (Creswell, 2007, p. 127) appeared particular relevant. We had cases that clearly resonated with the criteria of dialogue in crises, but still encompassed huge differences on the criteria, especially to how utterances were shared in time and space during the dialogues. By maximizing the differences in the selection of cases, we aim to increase the likelihood that the findings will explore our research question, but at the same time reflect differences or different perspectives, something that is aimed for in qualitative research. We also applied the criteria of "extreme and deviant cases" (Creswell, 2007, p 127), something that made us able to explore utterances and dialogues in crises, and at the same time show how such dialogues can make a difference in extreme situations in different settings.

It has not been our intention to end up with positive case studies or "success stories," however, through using the criteria above we ended up with three cases in which the dialogues had a positive mediating effect on the personnel in crises. Below is a brief description of the context of our study, encompassing the three cases, from the armed forces, the police and the health services.

The "Coaching in Crossfire" case is from the Norwegian Armed Forces (Special Forces). An army officer serves as a bodyguard in an international mission. The situation escalates into shooting, 
and the officer signals evacuation of the building to secure the Very Important Person (VIP). Suddenly he slaps a member of the entourage in the face.

The "Axe Desperado" case is from the Norwegian Police (Special Forces). A perpetrator acts desperately, swinging an axe into a door while shouting that he wants to kill as many people as possible. A team from the police point their guns at him and are prepared to shoot him. One police officer invites him into a dialogue.

The "Still Face" case is from the Norwegian Health Services. A therapist encounters a young man wearing a hoody covering his face, looking down onto the desk saying nothing. He seems like he does not want to relate to people anymore. Facing the still face, the therapist starts talking.

\section{Data Collection}

With a multiple case study design (Creswell, 2007), we found it important that the situations under investigation were already solved so our research did not entail placing any additional burden on the participants. They were members of the armed forces, police department, and health services in Norway. Indepth interviews with one person from each unit were conducted, lasting from 30 to $60 \mathrm{~min}$. The interview guide consisted of four main sections: Selection of the case, the context of the particular case under exploration, the reflecting dialogue that took place in the situation and whether or not actions were carried out. The interviews were audiotaped and transcribed verbatim to obtain accurate grounds for analysis (Creswell, 2007).

\section{Data Analysis}

When multiple cases are chosen, a typical format is first to provide a detailed description of each case and the themes within the case, called within-case analysis (Creswell, 2007, p. 75). The selection process of cases based on the criteria already presented, resulted in, as already presented, the following three cases:

(1) The Coaching in Crossfire

(2) The Axe Desperado

(3) The Still Face.

Having data from three different cases, we started by conducting a within-case data analysis of the transcriptions of the interviews. Material addressing the chosen case were examined for analysis while utterances addressing other cases or more general issues were omitted.

We moved from the narratives to a subject-oriented analysis where the data material was analyzed through coding and categorization. Coding is seen to be the pivotal link between collecting data and developing an emergent theory to explain the data material (Charmaz, 2006). Further analysis was based on open coding following Corbin and Strauss (2008), using the constant comparative method of analyses. This process started by bringing order to the material by attaching one or more code words to relevant text paragraphs. Through this process, we developed a table with extracts (utterances) in one column, code words in another and potential categories in a third column.

Through the process the transcription of each interview was developed into a table of between 3 and 5 pages, encompassing
TABLE 1 | An illustration the coding-process for case number two.

\begin{tabular}{|c|c|c|}
\hline Utterance & Code & Category \\
\hline $\begin{array}{l}\text { "Let me take over the talking here," I said to the } \\
\text { police officer shouting at the man. My intention } \\
\text { was to try to get through to the desperate man } \\
\text { with the axe in front of us. I thought we just had } \\
\text { to keep as calm a mood as possible. I did } \\
\text { everything I could to communicate clearly, but } \\
\text { in as calm a voice as possible. I was very aware } \\
\text { of the way I communicated with him, that I } \\
\text { used understandable words and that I talked as } \\
\text { clearly as possible so that he could understand } \\
\text { what was happening. I was very clear about } \\
\text { trying to calm him down. }\end{array}$ & $\begin{array}{l}\text { Talking } \\
\text { Get through } \\
\text { Communicate } \\
\text { Calm }\end{array}$ & $\begin{array}{l}\text { Unlocking } \\
\text { situations }\end{array}$ \\
\hline $\begin{array}{l}\text { Eventually, he changed his behavior from just } \\
\text { shouting that he was going to kill people to } \\
\text { actually talking to me. He began to respond to } \\
\text { me, stopped cursing and started to ask me } \\
\text { questions. Something had changed through the } \\
\text { conversation. }\end{array}$ & $\begin{array}{l}\text { Changed } \\
\text { Shouting } \\
\text { Talking } \\
\text { Questions }\end{array}$ & $\begin{array}{l}\text { The chain of } \\
\text { utterances }\end{array}$ \\
\hline $\begin{array}{l}\text { Afterwards, he said: "Because you kept your } \\
\text { voice low and calm, talked clearly to me, you } \\
\text { were able to reach through my shell." He had } \\
\text { the feeling that we saved his life that night, he } \\
\text { realized that in the worst case, we might have } \\
\text { had to kill him. }\end{array}$ & $\begin{array}{l}\text { Voice } \\
\text { Reach } \\
\text { through }\end{array}$ & $\begin{array}{l}\text { The impact } \\
\text { of auxiliary } \\
\text { stimulus }\end{array}$ \\
\hline $\begin{array}{l}\text { During the conversation, he suddenly grasped } \\
\text { what he was actually doing. It started to sink in } \\
\text { for him what was about to happen. The } \\
\text { conversation ended with him collapsing in my } \\
\text { arms and we hugged each other. }\end{array}$ & $\begin{array}{l}\text { Grasped } \\
\text { Sink in }\end{array}$ & $\begin{array}{l}\text { The } \\
\text { mediation of } \\
\text { higher } \\
\text { mental } \\
\text { functions }\end{array}$ \\
\hline $\begin{array}{l}\text { Suddenly we saw that the axe was gone. He } \\
\text { had calmed down so much now and we knew, } \\
\text { as far as possible, that he had no access to any } \\
\text { other weapons. I explained to him in detail what } \\
\text { was going to happen. I also said to him that he } \\
\text { had to do what we told him to do so that he } \\
\text { would not think that he suddenly had the power } \\
\text { in the situation. Then, the door opened; he } \\
\text { unlocked it from the inside and opened the } \\
\text { door quietly. He began to cry and tell his story. }\end{array}$ & $\begin{array}{l}\text { Axe was } \\
\text { gone } \\
\text { Opened the } \\
\text { door } \\
\text { Cry } \\
\text { Tell his story }\end{array}$ & $\begin{array}{l}\text { Renewed } \\
\text { volitional } \\
\text { action }\end{array}$ \\
\hline
\end{tabular}

the most relevant material from each case after analyzes. To illustrate the coding-process, a short version of the table used to analyze case two, The Axe Desperado, is shown below (Table 1).

The last stage in the data analysis was categorization, the process of gathering information about the same theme within its respective category (Charmaz, 2006). Based on this constantcomparative method of analyses (Corbin and Strauss, 2008), the following five categories were developed:

(1) Unlocking Situations

(2) The Chain of Utterances

(3) The Impact of Auxiliary Stimulus

(4) The Mediation of Higher Mental Functions

(5) Renewed Volitional Action.

Finally, we conducted a cross-case analysis (Creswell, 2007, p. 75). This process did not add any new categories, thus the same five categories were used to structure and analyze the data across the cases. 


\section{Ethical Considerations}

The informants were given an informed consent form stating that participation in the study was optional and that they could withdraw at any time without having to provide any reasons. The study was approved by the Norwegian Social Science Data Services (NSD) in 2019.

\section{RESULTS}

When presenting our findings, we start by providing a rich description of each case to give a feeling of "being there" before we dig deeper into the five analytical categories.

\section{Coaching in Crises - Description of Cases}

The rich description of the three cases presented below is written in a narrative format (with the pronoun "I" or "we") as they were told by the person who was the subject in each case.

\section{Coaching in Crossfire - Slap in the Face - 4 Seconds}

I was working as a bodyguard in the armed forces. This time, my duty was to guard a senior officer, a so called Very Important Person (VIP). Shortly before we were to drive away, it turned out that the VIP also wanted to bring a Military Assistant (MA) with him, a person whom I did not know.

We drove out to the meeting point, and went into the building and up the stairs to the second floor. We entered a large open room. The "warlord" was sitting behind a large desk with his guards around him. My VIP was sitting in front of the desk. The VIP and the warlord were sitting opposite each other. The negotiations seemed to be going well, and the mood seemed fine. Suddenly the warlord opened the desk drawer and took out a gun. He was holding it upside down, signaling that he was not planning to shoot, and then he put it slowly on the desk. I was very attentive and continually considering how to be able to protect the VIP. I was not very stressed, but I remained alert. However, the gun did something to us, the mood in the room changed.

Suddenly I heard a shot, it felt like being punched in the gut, my body reacted like that, but I quickly understood that it was some distance away. Then, more shots outside the building and a bullet hit one of my men in his arm. I pushed my VIP in front of me toward the corner at the opposite end of the room and kept him behind me in the corner. I had checked the walls and knew that it was safe in the corner right then. They could not shoot us from the outside where we stood, but we could not stay there for long, this was not a good situation.

The shooting stopped; now was my chance, and I signaled to my men that we were vacating the building. I took my VIP with me, pulling him after me, looking for any danger in the room. When I got to the middle of the room, I saw the MA just standing there, frozen like a stone statue. When I got closer, I saw something strange in his eyes; he was staring straight ahead, looking right through me with a 1000-yard stare. I let go of the VIP, slapped the MA right in the face, grasped his uniform on his right side up to the collar, shouting "You have to wake up, we're getting out of here!" He met my gaze, turned around, and I pushed him in front of me while I pulled my VIP after me. We scrambled down the stairs, and one of my men took hold of the MA, so I could push the VIP in front of me into the back of the car and lay down on top of him. Just when I was lying there as a living shield, with the door open and my legs down in the gravel, I thought "Now I can be shot from behind, now I can die." Nevertheless, it went well.

\section{The Axe Desperado - Words as Weapons - 40 Minutes}

When we came upon the scene, the situation inside the apartment was chaotic. There were literally police officers everywhere. Through the kitchen door we heard the man shouting multiple times that he wanted to kill as many people as possible. We could see the axe splitting through the door and could see his facial expression through the hole. This man is desperate, I thought. I was convinced that he would make a big enough hole in the door soon and come out and at us. We could not let him do that as it would endanger the lives of the other residents in the apartment block. We were prepared to shoot him.

"Let me take over the talking here," I said to the police officer shouting at the man. My intention was to try to get through to the desperate man with the axe in front of us. I thought we just had to keep as calm a mood as possible. I did everything I could to communicate clearly, but in as calm a voice as possible. I was very aware of the way I communicated with him, that I used understandable words and that I talked as clearly as possible so that he could understand what was happening. I was very clear about trying to calm him down.

Eventually, he changed his behavior from just shouting that he was going to kill people to actually talking to me. He began to respond to me, stopped cursing and started to ask me questions. Something had changed through the conversation. Something told me this could be a very sad and frustrated person who was just having a moment where he was acting completely irrationally. He was desperate, but to me, it seemed as if he genuinely wanted to find a peaceful solution.

I remember saying, "We'll probably find a way out of this, but first of all, you have to stop swinging that axe. If we want to make some progress here, you have to show me that you're willing to lay down your weapon." He replied: "I want you to put your weapons away, I don't want you pointing your guns at me." Then I said: "I can understand that, you don't want our guns pointing at you, so let's find a way out of this that'll be good for both of us."

I contacted my partner to check if he felt okay about going in there. Suddenly we saw that the axe was gone. He had calmed down so much now and we knew, as far as possible, that he had no access to any other weapons. I explained to him in detail what was going to happen. I also said to him that he had to do what we told him to do so that he would not think that he suddenly had the power in the situation.

Then, the door opened; he unlocked it from the inside and opened the door quietly. He began to cry and tell his story. We were facing an average person who might have had a breakdown, drunk some booze, and maybe taken some drugs as well. He had 
broken up with his girlfriend; there were many things that had been building up lately. The end result? He had given up. He did not care how this went, if he got injured or died. During the conversation, he suddenly grasped what he was actually doing. It started to sink in for him what was about to happen. The conversation ended with him collapsing in my arms and we hugged each other. Afterward, he said: "Because you kept your voice low and calm, talked clearly to me, you were able to reach through my shell." He had the feeling that we saved his life that night, he realized that in the worst case, we might have had to kill him.

\section{The Still Face - Feeling the Goodness - Forever}

I was doing a follow-up of a man who previously was seen by a colleague of mine. My colleague had made no progress with him and the client wanted to change his therapist. I tried to have a different focus when I met him and thought that I would try to find out what had happened that led him to isolate himself so much. It seemed like he did not want to relate to people anymore, just sitting in his room and playing computer games. Totally inaccessible.

When I first met him, he sat with his hoody covering his face so I was not able to see his eyes. He said nothing. I did not bring any checklists or assessment tools to this conversation because I believed that is not the way to interact with a young man. He still did not speak and I thought that was okay, and so I began talking.

I think we went through this six times, where I was the only one talking. During these meetings he did not look at me once, so these were special sessions. On the assessment form I wrote that I was conducting an investigation. I had to write something. He was just sitting there, listening, and I could barely remember what I was talking about really. I might say things like: "I don't know if you want to be here, what you think is important to you and I have heard something about this and that and, someone is worried and so on." I just continued to talk about these things and told him that he probably had good reasons to want to be secluded and I really wished I could know a little bit about why. "But I have plenty of time and I'll be working here for many years," I added. I just kept on talking like this in these sessions.

Then, in the seventh session, he came in and sat down just like before. At least it is good that he shows up, because one of the problems earlier was that he did not always show up for the sessions. For this meeting I had planned to be a little more personal. "I thought I could tell you a story from my private life." Then I told him about one of my kids who was struggling and who had quite a difficult time and who was doing some of the same things he was doing: Withdrawing from everybody and going through hard times. I talked about how hard it can be being a young person today. "You feel lonely and all this loneliness kind of grows on you. I don't know if that's what you feel, but for my daughter, she felt like that." Then he suddenly looks up. I was able to look him in the eye for the first time and I remember that for me it was a very emotional moment: that he actually looked at me. Then he said something. I am not able to remember what he said, but the fact that he said something, asked some questions about my daughter, that was amazing.
For the next session, he did not have the hoody covering his face. This was something completely new. I could finally see the nice man behind that hoody. He said: "I've done a lot of thinking since last time." I was just amazed that he was actually talking to me; he looked at me, looked me in the eye. I was excited and I could feel good for him. He continued: "I think you're someone I can trust and I have a story to tell." He told me a horrible story about being bullied at school. They had driven him to the point that he had considered doing something drastic. He was very emotional when he told me this. Tears were streaming down his face. I listened to his story; and thanked him for sharing it with me, and then we both cried together.

The emotional pressure had been released. He was not in the same dark place as when he first came to the treatment sessions. He continued to come back. We worked like that for about 2 years. Recently I received a message from him that he now has a girlfriend and that they have bought a house. Daily life makes sense to him now. He is very grateful for the job we did together.

The most intense moment for the conversations was when I shared something from my own life, when he raised his head and looked me in the eye. I can still feel it when I now talk about it now, I still get emotional. It was a very profound moment. That he actually dared to look at me and that he had the courage to face me. So much shame and the experience he had had of not being accepted.

\section{Coaching in Crises - Analyzing the Cases}

The five categories derived from the three case structures in the analysis are presented below.

\section{Unlocking Situations}

Real-life experiences play out in situations in which both person variables and situation variables contribute to behavior (Mischel, 2004). Looking back on these crisis situations, we can see how the people involved are subject to a person-situation influence in the moment, stretching from four seconds to hours, even years.

In the crossfire situation, the firing stopped and the bodyguard responsible for the VIP signaled for evacuation of the building, to which the MA responds by freezing up, frozen like a stone statue, and with a 1000-yard stare. With the MA out of play, the bodyguard had to solve the situation and was under enormous time pressure. How can we understand this moment? The turning point that unlocks the situation seems to be the use of quick dialogic responses.

Similarly, the situation with the axe man shouting that he wanted to kill people and police officers pointing their guns at him was extremely chaotic. Between the shouting and the firearms, one police officer invited the man into a communication process. Here the turning point is the dialogue itself, chosen over violent reactions.

Finally, the therapist, facing a young man sitting in front of her with a hoody covering his face also offers a good example of persistence in offering dialogic exchanges. When she talked, he avoided eye contact and said nothing. She was the only one talking while getting no response for hours. What unlocked the young man's behavior was the therapist's stubborn commitment to a dialogic situation. She shaped the room and opportunity for 
conversation, without knowing if she could expect or was going to get a response.

Looking across these situations, it is hard to make sense of the decisive moments or find one single best practice: The first situation is coped with by slapping "the other" in the face, the second by inviting "the other" into a communication process using a calm and clear voice, while the third situation turns on the therapist simply being there, talking, unconditionally, persistently.

Even the use of time or timing is hard to understand: The bodyguard took advantage of the moment, using about $4 \mathrm{~s}$, the police officer stretched the moment of time from seconds to $40 \mathrm{~min}$, and changed the situation, gradually, utterance by utterance, whereas the therapist acted beyond time, time was not an issue, as if she was going to be there forever. However, what these three responses seem to have in common is the capacity to unlock the moment, a transformational force from problem to solution.

\section{The Chain of Utterances}

Being part of the situations above also means being part of a dialogue in which both parties mutually affect each other through their utterances, and thus are subject to change in relation to the other (Bakhtin, 1986).

In the crossfire situation, when the bodyguard discovered the MA with a 1000-yard stare, he faced a dilemma: He could have bypassed the MA, thinking "take care of yourself; I'm responsible for the VIP" or enter into a dialogue. These utterances played out:

(1) The bodyguard slaps the MA right in the face, and shouts "you have to wake up."

(2) The MA meets the gaze of the bodyguard and turns around.

(3) The bodyguard pushes the MA in front of him.

(4) They carry on down the stairs.

In the axe-man situation, the police officer faced a dilemma: He could have pointed his firearm at the desperado or tried to create a dialogue. From there the following utterances played out:

(1) The police officer keeps a calm mood and a calm voice.

(2) The axe man changes his behavior from shouting "I want to kill as many people as possible" to actually talking.

(3) The policeman says, "We'll probably find a way out of this, but first of all, you have to stop swinging that axe."

(4) The axe man replied: "I want you to put your weapons away, I don't want you pointing your guns at me."

(5) The police officer says: "I can understand that, you don't want our guns pointing at you, so let's find a way out of this that'll be good for both of us."

The therapist faced a dilemma: She could have put a mark in the protocol and ended the treatment or she could invite the young man into a dialogue. From there the following utterances played out:

(1) The therapist starts talking.

(2) The patient does not look at the therapist once for hours, he just sits there, listening.
(3) The therapist feels that this was special and shares a story from her personal life.

(4) The patient suddenly looks up and starts talking.

(5) The therapist finds this profound.

In all the dialogues, we see how the utterances form "a link in the chain of utterances, a speech communication" (Wertsch, 1991, p. 52), where the emergency personnel ensure that their utterances establish contact with "the other." Finally, we see how the emergency personnel make themselves vulnerable; they go through a change in relation to the recipient to cope with the situation. The bodyguard makes himself vulnerable for four seconds when he loosens his grip on the VIP. The police officer listens to the voice shouting: "I want to kill as many people as possible." The therapist experiences the process of rejection for hours.

\section{The Impact of Auxiliary Stimulus}

In the process of double stimulation, the subject is directed by a group of stimuli in the activity or tasks at hand until a second stimulus becomes a sign or an artifact that links the outside world with inner psychological functioning (Vygotsky, 1931/1994).

In the crossfire case the problematic situation is dominated by the first stimulus. The bodyguard signals evacuation and the MA has frozen: The situation is locked. However, we can imagine how the slap, the grasp in the uniform and the shouting functioned as second stimuli. The second stimuli clearly had an immediate effect; the MA unfroze and started to move.

The axe-man case is also a problematic situation dominated by the first stimulus. The axe-man swings his axe and shouts and the police point their firearms and shout: The situation is locked. However, the police officer's utterances, which cannot be separated from the axe man because they continuously influence each other, act as auxiliary stimuli: They simulate the axe-man's thinking. Words have become a link between the outside world and his inner psychological functioning. The axeman puts it like this: "Because you kept your voice low and calm, talked clearly to me, you were able to reach through my shell."

Initially the Still-Face case is a totally locked situation dominated by first stimulus: The patient is caught in his loneliness and anxiety, and the therapist experiences rejection. However, after hours of talking, a personal narrative functioned as a second stimulus. The patient suddenly looked up, met her eye and started talking. When encountering trust and respect, we can imagine how the therapist created a second stimulus for the situation, giving the patient a link between himself and the outside world.

As evident from the examples above, the nature of the second stimulus varies across the situations. The emergency personnel create a second stimulus that reaches into the person in a crisis, a stimulus created in relation to the situation, "in situ," in a way that has impact on "the other." Only then can the stimulus become a traceable link between the outside world and the inner psychological functioning of "the other." This second stimulus reveals and makes accessible resources that would have been hidden without this external impact. 


\section{The Mediation of Higher Mental Functions}

What we have seen is that a new stimulus plays the role of stimuli-means and leads to a transition from a lower to a higher form of thinking and then to a change in behavior (Matiyshkin, 1997, p. 266).

We can only imagine how it would be to be in a frozen position, standing like a stone statue. From this point, the bodyguard uses non-verbal and verbal language to make an impact on the MA: Slap in the face, grasping the uniform and shouting. These stimuli definitely have an impact, from the MA being literally unable to think and behave, these stimuli trigger the thought process and change of behavior: The MA actually starts moving. This thought process was most likely not very advanced or of a higher order, we interpret this rather as a transition from no-thinking to lower thinking, however, this transition is just as important.

The axe-man case encompasses a range of stimuli-means ranging from weapons to words. Initially the axe man wields his axe and uses rude language, while the police officers have their firearms and a speech genre of command. However, gradually the language acquires the dominant role. The utterances, functioning as auxiliary stimuli, influence the thinking of both the axe man and the police officer. We remember the axe man saying: "you were able to reach through my shell." The police officer had the following experience: "during the conversation, he grasps what he is actually doing. It starts to sink in for him what was about to happen." These utterances mediate the axe man's thinking, leading to a transition from a lower to a higher form of thinking - and a new organization of behavior occurred.

Concerning the Still-Face case, it can be supposed that, while he sat for hours without saying anything, the young man received an enormous amount of high-quality stimuli. The human voice must have had an impact on him. Finally, the therapist's sharing of something personal about her daughter must have triggered a new form of thinking. We do not know if this is the result of the trust-building process or the actual content of the shared story about the therapist's daughter. The response: "I think you're someone I can trust; I have a story to tell" triggered the start of the transition process in which they practiced, for 2 years, to mediate a new form of thinking and behavior.

In all three cases, we see how language functions between people (interpsychological) and then inside the human (intrapsychological). This shows that human uses language in communication and as a tool in his or her own thinking, something Wertsch named "semiotic mediation" (Wertsch, 1998).

\section{Renewed Volitional Action}

Through double stimulation mediating higher mental functioning we bridge into conflicts of motives and volitional action. Such volitional action is carried out under conditions of poly-motivation, where some motives have positive affective signs and others have negative ones (Leont'ev, 2005, p. 80). This is evident from our cases which encompass a mix of stimuli.
The bodyguard was caught in a dilemma, take care of his VIP or help the MA out of his frozen position, but not for very long. Within $4 \mathrm{~s}$ he solved the conflict of motives, acting out a will to save them both. With the MA standing there like a stone statue, the conflict of motives may have been like this: On the one hand, he was so afraid that he was nailed to the spot and on the other hand he wanted to shake off his anxiety, think clearly and get moving out of the situation. If he remained standing still he would probably die, of course he wanted to turn around and run for his life. The stimuli from the bodyguard brought him to his senses and he was able to carry out his volition action.

The axe-man case is rather complex with many conflicting motives. The police officer is responsible for the safety of his partner and all the residents of the apartment block, on the one hand, and for treating the axe man with respect on the other. He did not want his fellow officers to move in or the axe man to act out. In this conflict of motives he expanded the time, expanded the dialogue and explored a peaceful solution. The axe man was experiencing a breakdown and did not care if he killed people or if he died, he had lost his senses due to his free-will action. However, after the police officer reached through his shell and into his mind, the human voice demanded him to stop acting out and offered a peaceful solution. From these conflicts of motives, the volitional actions played out: He opened the door and collapsed in the arms of the police officer.

The therapist was caught between the need to set a diagnosis and the will to interact with the other, where the former is easy while the latter is hard. Through the conflicting motives, she performed volitional action: "She feels so good for this boy," thus she chose to sit there talking while the only response was a "still face" for hours. The young man with the hoody was in such great pain that he wanted to die, however, he also felt human kindness in the encounter with the therapist. From these conflicts of motives, the volitional actions played out: The young hoody man looked up and started talking. He chose to practice his way back to social life. What is evident from all these three cases is that all people involved experienced a conflict of motives with dialogues - encompassing double stimulation - on the one hand, and volitional action on the other. Right here, time, timing and the art of the moment were decisive.

\section{DISCUSSION}

This study's exploration of the three narratives has revealed the five categories presented above. The findings explored communication in crises. However, our research has taken this topic a step further by digging deeper into the dialogue to explore how creating auxiliary stimuli can mediate people's higher-order thinking and voluntary actions. Below we will discuss how our findings resonate with relevant literature (perspectives outlined above, but our findings have also addressed other perspectives) and elaborate on their implications.

\section{Being an Expert}

Our research mirrors the controversy of being an expert (Dreyfus and Dreyfus, 1986). Strategies for coping with crises are situated, 
i.e., an in situ type of knowledge. Emergency personnel cannot just apply the rules from a manual, nobody can, but this professional group is more dependent on appropriate situated reactions because they are dealing with matters of life and death. They must be persistent (regardless sorrow, hurt, and pain), cope, and stay focused as long as the problem lasts (Haraway, 2016). These experts observe, reflect, analyze, and assess the situation, and make appropriate timely decisions: Sometimes in a very short amount of time and other times by expanding or stretching time. What is interesting is the fact that they can bypass the reflection processes and act appropriately in new situations. This then concurs with the definition of creativity: to do something that is new/original and appropriate in a given context (Chemi et al., 2015). Expertise is the core of this process (mastering): Only if knowledge is embodied and internalized can individuals act instinctively, creatively, and appropriately. Emergency experts act out their knowledge by taking part in an internalized, embodied dialogue where expertise is the background knowledge on/with which the professional can improvise. Utterances are verbal, in the sense of saying the right words, but also very much non-verbal: body language, tone, and rhythm (Stanislavski, 1936/2013). This bodily communication plays out between the people in a crisis situation. Their reflection process is instinctive and relational. It reminds us of what actors do when something goes wrong on stage. The strategy they employ is to hold each other's gaze, they become one, not really a form of communication, but more a matter of thinking, feeling, and reacting as one. According to Sawyer (2014), this embodied knowledge that allows for improvisation is also found in jazz improvisation. Master musicians apply their internalized knowledge to the music performance, and only against that background of this bodily knowledge can they "jam" with each other and find impromptu solutions to emerging (musical, compositional) problems. As an expert, you dare to involve yourself in the situation, and you trust your emotions and intuitions (Dreyfus and Dreyfus, 1986).

\section{Human Relations}

Some concepts are important elements in the dialogue, where double stimulation and auxiliary stimulus appear to be the key to changing others' thinking and actions (Vygotsky, 1931/1994; Bakhtin, 1986; Sannino, 2015). A number of researchers have studied how communication skills (Greenstone, 2004) and therapeutic approaches build relationships to solve a crisis (Grubb et al., 2020). Our research complements these theoretical approaches and studies by digging deeper into how the dialogue is a shared process of human relations. Our research demonstrates that dialogue with the other means taking part, changing roles, being a speaker one moment and a listener the next, and letting the parties affect each other in the dialogue (Bakhtin, 1986). Each person's response is guided and shaped by the response from the other, they interact like they are "dancing" (Hargie, 2006, p. 13). The dialogue is a shared process where both interlocutors are subject to change in relation to the other. Emergency personnel acting with human kindness and taking the risk of being vulnerable stimulated the shared process and mutual change. Our study thus suggests that showing vulnerability is key to making the dialogue a shared process and to releasing the hidden potential of being human. The expert who let go of the VIP to save the MA, the police officer and the axe man hugging each other, and the therapist and patient crying together, illustrate humanity. This gives associations to the words of Martin Buber: "only when all means have disintegrated do encounters occur" and "all actual life is encounter" (Buber, 1996, p. 62-63). By daring to be human, you can make the other human.

\section{Embodied Emotions}

Our study illustrates the impact of emotions in a crisis. The opening of Homer's Iliad introduces us to Achilles' anger (Homer, 1992). He was a very powerful Greek warrior, but one of his weaknesses was his uncontrollable rage. Emotions are an integral part of human response to stressful situations and to how we cope with such situations (Lazarus and Folkman, 1984; Flin, 1996). In our first case, the overwhelming stress in the shooting situation with emotional stress reactions made the MA go into an emotional state of "freeze." The slap in the face, delivered by the emotionally controlled expert, brought him back to reality, he "woke up." In the axe-man case, the person in the crisis was emotionally hijacked by his emotions leading to an enormous rage where he wanted to kill people. The police officer's emotional regulated calmness was the key to reaching into his mind and getting him to calm down. In the hoody-man case, the person in crisis was blocked by his strong feelings of anxiety, guilt, shame, sorrow, and anger. Only the feeling of human kindness, a kind of love, as expressed by the therapist, got him to unlock his emotions and show the courage to relate to other people. Our findings expand our understanding of how emotional intelligence can make a difference. While the one party is captured by emotions, and to some extent emotionally high-jacked by their emotions, the experts try to use their emotional intelligence (Goleman, 2006). Instead of trying to bypass emotions, pretending they are not there, they seem to encompass and use the embodied emotions to their advantage, their own and the emotions of the other, in the process of solving the crises situation at hand (Drodge and Murphy, 2002).

\section{Interpersonal Expectancy}

Our study brought the process of interpersonal expectancy into new contexts. According to Greek mythology, Pygmalion was a sculptor who was hopelessly in love with one of his statues and asked the goddess Aphrodite to bring it to life, and the statue came alive and loved him back. The research article "Pygmalion in the Classroom" shows that the Pygmalion effect also applies in school (Rosenthal and Jacobson, 1968). Rosenthal and Jacobson informed teachers that some randomly selected students in a class were particularly promising, creating an expectation that over time produced the expected effect, measured by improvement in IQ scores. Many years later Rosenthal summed up 40 years of research on interpersonal expectancy, concluding that one person's expectations for another person's behavior become a self-fulfilling prophecy (Rosenthal, 2002). Reflecting back on our three cases, we argue that interpersonal expectancy made a difference. Traditionally, 
expectancies has been seen as mostly a cognitive matter. However, on bases on our study's findings, we argue that it is reasonable that also emotions and embodied knowledge may also have impact in a crisis.

\section{Possible Limitations, Implications}

Having investigated how emergency personnel use dialogue to mediate other people's actions in a critical situation by examining three unique cases from the armed forces, the police and the health services in Norway, one may question if our findings can be generalized to other situations. Bearing this in mind, we argue that this study has the potential for "naturalistic generalization" (Stake, 1995) in which one argues for the understanding of research through a more intuitive approach, through people's experiences (Lincoln and Guba, 1985).

The study has theoretical implications as it broadens our knowledge of the dialogue as a shared process in which double stimulation encompassing the auxiliary stimulus is the key to mediating thinking and action in crises. Our research reduces the gap in our understanding of communications skills (Greenstone, 2004) and crisis negotiations (Grubb et al., 2020).

\section{Practical Contributions}

Moreover, the study has revealed practical contributions as dialogue in crises has shown that emotional competence "mediates the social process of leadership" (Drodge and Murphy, 2002). It is our strong belief that these narratives, combined with associated knowledge of the dialogues, can help professionals to perform better in future crises. We argue that our research has the potential to contribute to leadership education in operative units, such as the armed forces, police, fire fighters, and medical services. The in-depth knowledge of how the dialogues have an impact on other people's higher order thinking and volitional action resonates with two opportunities of education.

Firstly, we would argue that these professions should aim for an experience based education with a combination of action and reflection (Dewey, 1961). Precious research from The Royal Norwegian Air force illustrates how this may be done: Facilitating crises situation where students can practice their ability to take advantage of the dialogue as oppose to action, followed by extensive reflection processes propelled by process oriented writing and coaching (Firing and Laberg, 2010; Firing et al., 2018).

Secondly, we would encourage leaders to take real world crises as opportunities for learning and leader development by putting emphasis on debriefing between missions. To be able to learn from the dialogue in crises we argue for a Holistic Debriefing (Folland, 2009). Traditional Debriefing is deeply rooted in the armed forces, a practice where participants talk through what happened in the incident to learn from it, however as the focus for the most part is on what happened and associated thoughts, the emotional dimension may be ignored (USArmy, 2011). Psychological Debriefing, is rooted in the health service and associated with crises, where one talk through the event focusing on emotions, under guides of specially trained personnel to avoid traumatic reactions (Mitchell, 1983; Dyregrov, 1989). Holistic Debriefing combines the Traditional Debriefing (used in the armed forces) and Psychological Debriefing (rooted in the health service) by explicitly addressing action, cognition, emotional and relation aspects of the mission (Folland, 2009). Even though Holistic Debriefing has been associated with traumatic events, such as the terror attack at Utøya, Norway, in 2011 (Firing et al., 2015), it is well suited for learning from a variety of crises.

To learn from dialogue in former crises, you have to reflect back on the event from a holistic perspective encompassing the action and cognitin, but also emotions and relations. This can be challenging in professions such as police, military, fire protection and medical treatment where the sharing of emotions and relations may be associated with being weak and vulnerable. In light of this study's findings, to ignore this would be an Achilles to leadership education in action-based professions: In addition to proper action and cognition, emotional intelligence and relational competence are core abilities to participate in shared dialogues where one can mediate other peoples' thoughts and actions in crises.

\section{Closing Comments}

In this study, we have explored how dialogue can mediate other people's actions in a critical situation, with a clear focus on the shared process. We are extremely grateful to the emergency personnel who participated in this case study, and to the people involved on "the other side" who had their lives changed during these dialogues. We feel humbled by the willingness these experts have shown in sharing their personal, emotional, and vulnerable experiences from the crises. We are proud to pass on their stories of dialogue in crises so that others may learn from them. The humanity shown by these experts has made us more human in our daily lives.

Achilles' uncontrollable anger reminds us about the nature of human life (Homer, 1992). These experts remind us of the courage to involve yourself in stress situations and still trust your emotions and intuition (Dreyfus and Dreyfus, 1986). They made an important difference when they reached out and into the other human during the dialogues.

\section{DATA AVAILABILITY STATEMENT}

All datasets presented in this study are included in the article/supplementary material.

\section{ETHICS STATEMENT}

The studies involving human participants were reviewed and approved by the NSD - Norwegian Centre for Research Data. The professionals/participants provided their written informed consent to participate in this study.

\section{AUTHOR CONTRIBUTIONS}

KF designed the study, assisted the data gathering and the data analyses, and drafted the manuscript. KS carried out the data gathering and performed the data analyses. MP assisted in designing the study, helped out with the methodology, 
and contributed with relevant theoretical perspectives to the study. TC contributed with theoretical perspectives and helped

\section{REFERENCES}

Bakhtin, M. (1986). Speech Genres and Other Late Essays. Austin, TX: University of Texas Press.

Bakhtin, M. (1998). Spørsmålet om Talegenrane. Bergen: Ariadne forlag.

Berglund, N. (2007). Obiora Case to be Reopened. Available online at: http://www. aftenposten.no/english/local/article1861327.ece (accessed June 28, 2007).

Berglund, N. (2008). Ali Farah Relieved Over Discrimination Ruling. Available online at: http://www.aftenposten.no/english/local/article2333859.ece (accessed March 28, 2008).

Brewer, M. B., and Gardner, W. (1996). Who is this "we"? Levels of collective identity and self representations. J. Pers. Soc. Psychol. 17, 83-93. doi: 10.1037/ 0022-3514.71.1.83

Buber, M. (1996). I and Thou. New York, NY: Touchstone.

Charmaz, K. (2006). Constructing Grounded Theory: A Practical Guide Through Qualitative Analysis. London: Sage.

Chemi, T., Jensen, J. B., and Hersted, L. (2015). Behind the Scenes of Artistic Creativity: Processes of Learning, Creating and Organising. Frankfurt am Main: Peter Lang.

Corbin, J., and Strauss, A. (2008). Basics of Qualitative Research: Techniques and Procedures for Developing Grounded Theory. Los Angeles: Sage.

Creswell, J. W. (2007). Qualitative Inquiry and Research Design. Choosing Among Five Traditions. Thousand Oaks, CA: Sage.

Dewey, J. (1961). Democracy and Education. An introduction to the Philosophy of Education. New York, NY: The Macmillan Company.

Dreyfus, H. L., and Dreyfus, S. E. (1986). Mind Over Machine: The Power of Human Intuition and Expertise in the Era of the Computer. New York, NY: The Free Press. Macmillan, Inc.

Drodge, E. D., and Murphy, S. A. (2002). Interrogating emotions in police leadership. Hum. Resour. Dev. Rev. 1, 420-438. doi: 10.1177/1534484302 238435

Dyregrov, A. (1989). Caring for helpers in disaster situations. Psychol. Debriefing. Disast. Manag. 2, 25-30.

Firing, K., Johansen, L. T., and Moen, F. (2015). Debriefing a rescue mission under a terror attack. Leadersh. Organ. Dev. J. 36, 78-89. doi: 10.1108/LODJ-12-20130169

Firing, K., and Laberg, J. C. (2010). “Training for the unexpected: how reflection transforms hard action into learning experiences," in Enhancing Human Performance in Security Operations: International and Law Enforcement Perspectives, eds P. T. Bartone, B. H. Johnsen, J. Eid, J. M. Violanti, and J. C. Laberg (Washington, DC: Charles C. Thomas LTD), 229-244.

Firing, K., Skarsvåg, K., and Chemi, T. (2018). "Using "the staged cocktail party" to improve leaders' social interaction in the norwegian military," in Sensuous Learning for Practical Judgment in Professional Practice. Volume 1: Arts-Based Methods, eds S. Taylor and E. Antonacopoulou (London: Palgrave Macmillan), 195-219. doi: 10.1007/978-3-319-98863-4_9

Flin, R. (1996). Sitting in the Hot Seat. Leaders and Teams for Critical Incident Management. Chichester: Wiley.

Folland, R. (2009). Holistic Debriefing: A Paradigm Shift in Leadership. Alabama: Air Command and Staff College, Air University Alabama.

Goleman, D. (2006). Emotional Intelligence. New York, NY: Bantam Books.

Greenstone, J. L. (2004). Communicating effectively for successful hostage negotiations and crisis intervention. J. Police Crisis Negotiat. 4, 43-52. doi: 10.1300/J173v04n02_06

Grubb, A. R., Brown, S. J., Hall, P., and Bowen, E. (2020). From deployment to debriefing: introducing the D.I.A.M.O.N.D. model of hostage and crisis negotiation. Police Pract. Res. 21, 1-24. doi: 10.1080/15614263.2019.1677229

Haraway, D. J. (2016). Staying With the Trouble: Making Kin in the Chthulucene. Durham: Duke University Press.

Hargie, O. (2006). "Skill in theory: Communication as skilled performance," in The Handbook of Communication Skills, ed. O. Hargie (London: Routledge).

Homer (1992). The Iliad. London: Penguin Classics.

Knutsson, J., and Strype, J. (2003). Police use of firearms in norway and sweden: the significance of gun availability. Polic. Soc. 13, 429-439. doi: 10.1080/ 1043946032000105381 to draft the manuscript. All authors read and approved the final manuscript.

Larsen, R. P. (2001). Decision making by military students under severe stress. Milit. Psychol. 13, 89-98. doi: 10.1207/s15327876mp1302_02

Lazarus, R. S., and Folkman, S. (1984). Stress, Appraisal, and Coping. New York, NY: Springer.

Leont'ev, A. N. (2005). Will. J. Russ. East Eur. Psychol. 43, 76-92. doi: 10.1080/ 10610405.2005.11059256

Lincoln, Y. S., and Guba, E. G. (1985). Naturalistic Inquiry. London: Sage.

Matiyshkin, A. M. (1997). “Epilogue," in The Collected Works of L. S. Vygotsky. The History of the Development of Higher Mental Functions, Vol. 4, ed. R. W. Rieber (New York, NY: Plenum), 261-278.

Mischel, W. (2004). Toward an integrative science of the person. Annu. Rev. Psychol. 55, 1-22. doi: 10.1146/annurev.psych.55.042902.130709

Mitchell, J. T. (1983). When disaster strikes the critical incident stress debriefing process. J. Emerg. Med. Serv. 8, 36-39.

Rosenthal, R. (2002). Covert communication in classrooms, clinics, courtrooms, and cubicles. Am. Psychol. 57, 839-849. doi: 10.1037/0003-066x.57. 11.839

Rosenthal, R., and Jacobson, L. (1968). Pygmalion in the classroom. Urban Rev. 3, 16-20. doi: 10.1007/bf02322211

Sannino, A. (2015). The principle of double stimulation: a path to volitional action. Learn. Cult. Soc. Interact. 6, 1-15. doi: 10.1016/j.lcsi.2015.01.001

Sawyer, R. K. (2014). Group creatIvity: Music, Theater, Collaboration. New York, NY: Routledge.

Shannon, C. E., and Weaver, W. (1949). A Mathematical Model of Communication. Urbana, IL: The University of Illinois Press.

Stake, R. E. (1995). The Art of Case Study Research. Thousand Oaks, CA: Sage.

Stanislavski, C. (1936/2013). An Actor Prepares. London: Bloomsbury.

USArmy (2011). Leader's Guide to After-Action Reviews (AAR). Kansas: US Army Combined Arms Center-Training.

Valsiner, J. (2000). Culture and Human Development. London: Sage.

Vygotsky, L. S. (1978). Mind in Society. The Development of Higher Psychological Processes. Cambridge, MA: Harvard University Press.

Vygotsky, L. S. (1986). Thought and Language. Cambridge, MA: MIT Press.

Vygotsky, L. S. (1997a). Educational Psychology. Boca Raton, FL: St Lucie Press.

Vygotsky, L. S. (1997b). “The history of development of higher mental functions, Chapter 12: Self-control," in The Collected Works of L. S. Vygotsky. The History of the Development of Higher Mental Functions, Vol. 4, ed. L. S. Vygotsky (New York, NY: Plenum), 207-219.

Vygotsky, L. S. (1999). "Tool and sign in the development of child, conclusion," in The Collected Works of L. S. Vygotsky. Scientific Legacy, ed. L. S. Vygotsky (New York, NY: Plenum), 61-68.

Vygotsky, L. S. (1925/1979). Consciousness as a problem in the psychology of behaviour. Soviet Psychol. 4, 3-35. doi: 10.2753/rpo1061-04051 7043

Vygotsky, L. S. (1926/1997). “Thinking as an especially complex form of behavior," in Educational Psychology, ed. L. S. Vygotsky (Boca Raton: St. Lucie Press), 157-180. doi: 10.4324/9780429273070-9

Vygotsky, L. S. (1931/1994). “The development of thinking and concept formation in adolescence," in The Vygotsky Reader, ed. V. D. Veer (Oxford: Backwell), $185-265$.

Wertsch, J. V. (1991). Voices of the Mind. A Sociocultural Approach to Mediated Action. Cambridge, MA: Harvard University Press.

Wertsch, J. V. (1998). Mind as Action. New York, NY: Oxford University Press.

Conflict of Interest: The authors declare that the research was conducted in the absence of any commercial or financial relationships that could be construed as a potential conflict of interest.

Copyright (c) 2020 Firing, Skarsvåg, Chemi and Postholm. This is an open-access article distributed under the terms of the Creative Commons Attribution License (CC BY). The use, distribution or reproduction in other forums is permitted, provided the original author(s) and the copyright owner(s) are credited and that the original publication in this journal is cited, in accordance with accepted academic practice. No use, distribution or reproduction is permitted which does not comply with these terms. 